Bressani, R. (1966). Proc. High Lysine Corn Conference (Corn Industries Research Foundation), Washington, DC p. 34 .

Clark, H. E., Allen, P. E., Meyers, S. M., Tuckett, S. E. \& Yamamura, Y. (1967). Am. F. clin. Nutr. 20, 825 .

Cromwell, G. L., Pickett, R. A. \& Beeson, W. M. (1967). F. Anim. Sci. 26, I325.

FAO/WHO (1965). F.A.O. Nutr. mig Rep. Ser. no. 37; WHO tech. Rep. Ser. no. 3or.

Haunold, A., Johnson, V. A. \& Schmidt, J. W. (r962). Agron. F. 54, zo3.

Johnson, V. A., Mattern, P. J. \& Schmidt, J. W. (1967). Crop Sci. 7, 664.

Johnson, V. A., Schmidt, J. W. \& Mattern, P. J. (1968). Econ. Bot. 22, 16.

Johnson, V. A., Schmidt, J. W., Mattern, P. J. \& Haunold, A. (1963). Crop. Sci. 3, 7.

Mertz, E. 'T. (1968). Agric. Sci. Rev. Third Quarter, p. I.

Mertz, E. T., Bates, L. S. \& Nelson, O. E. (1964). Science, N.Y. 145, I701.

Mertz, E. T., Veron, O. A., Bates, L. S. \& Nelson, O. E. (1965). Science, N.Y. 148, 1741.

Osborne, T. B. \& Mendel, L. B. (I914). 7. biol. Chem. 17, 325.

Pradilla, A. \& Harpstead, D. (r g68). Data from Department of Pediatrics, Universidad del Valle, Cali, Colombia, South America.

Sreeramulu, C. \& Bauman, I. F. (1968). Proc. Am. Soc. Agron. New Orleans, La.

Stuber, C. W., Johnson, V. A. \& Schmidt, J. W. (1962). Crop Sci. 2, 506.

\title{
The prospects of breeding barley, wheat and oats to meet special requirements in human and animal nutrition
}

\section{By R. N. H. Whiтehouse, Plant Breeding Institute, Trumpington, Cambridge}

The attention given by cereal breeders in this country to the chemical composition of grain has been much less than that given to what may be called farmers' characters. Where it has been given, attention has been limited to a few fields, particularly those related to bread and beer, namely the milling and baking properties of wheat and the malting and brewing qualities of barley. Feeding value as a character has been largely neglected until recently and, indeed, grain for feeding purposes was often that which failed to meet the quality requirements of millers and maltsters. Some official encouragement was given to oat growers to promote the use of varieties low in husk or high in oil content, but farmers on the whole have preferred varieties with high total yield.

While this paper is primarily concerned with biological problems, it is worth mentioning that in a free society economic forces largely determine which varieties are grown. If price support is not forthcoming for grain of special chemical composition there is every likelihood that such varieties will be neglected by farmers. This is because the addition of chemical selection criteria limits the breeder's choice of both parental and hybrid material, with the result that he may fall behind in the race to produce varieties heading the yield list of those recommended for cultivation. It may not therefore be worth embarking on a i 5 -year research programme, however good the scientific prospects, if the product is doomed to economic failure.

\section{Plant breeding procedures}

In order to appreciate the problems facing the breeder who contemplates making changes in quality characters, it is necessary to understand the methods he may use. A breeding programme may conveniently be divided into a series of steps, the first 
of which is to define the problem to be tackled and make sure that it should be resolved by breeding and not by changes in husbandry or manufacturing processes. It has often proved very difficult to translate the empirical requirements of traditional industries, such as baking or brewing, into precise statements of quality with which a breeder could work. The components of nutritive value are better documented but the varying requirements of different classes of livestock and the numerous ways of estimating feeding quality lead to a complex situation.

As a second step in organizing breeding for quality it is necessary to choose or, more often, devise tests suited to screening large numbers of plants or grain samples. It is sometimes the case that tests suggested by chemists, although capable of giving accurate assessments from 50 or a $100 \mathrm{~g}$ of grain, can be used to handle only a few samples per week. Tests offered by nutritionists tend to be more unsuitable since several months, and 50 or a $100 \mathrm{~kg}$, may be needed for feeding trials. Plant breeders are likely to require an initial screening test which demands only a few grams of grain and will readily adapt to an automated system capable of handling hundreds of samples per week. Fortunately the initial test need not be highly accurate since more precise tests can be applied to any plant material suspected of displaying the required character.

Having established a screening procedure, plant material must next be surveyed to discover the range of variability existing in the crop. Testing would begin with varieties in common use and then proceed to collections of varieties drawn from the main regions of the world in which the crop is grown. This might involve many thousands of varieties. If no adequate source of genes for the character is found in this way, recourse must be had to other methods. It may be possible to increase the expression of the character to an acceptable level by hybridizing varieties each of which expresses it weakly. Alternatively a survey could be made of related species from which genes or chromosome segments could be extracted by suitable cytological techniques. A further procedure would be to embark on a programme of inducing mutations by treatment of seeds or meristematic tissue with radiation or mutagenic chemicals. This would have to be followed by extensive screening tests. Finally there remains the possibility of mounting a collecting expedition to the centre of origin of the species to search for additional plants. This also would need to be followed by screening tests.

Once a source or sources of suitable genetic material have been isolated, breeding work can begin. In parallel with this, genetic and environmental effects will require investigation. Information will be assembled concerning the heritability of the character, the number and dominance of the genes affecting it and the existence of modifying genetic systems. Without this information it may prove difficult to maintain, let alone improve, the expression of the character, especially as this is likely to be affected by environmental conditions as well. Growing conditions for the crop must be found which permit repeatable results in the screening test. Changes in water or fertilizer regimes or the presence of disease may influence the composition of grain and make selection difficult.

To give high yields, varieties have to be adapted to the environmental conditions, 
both natural and agricultural, of the area in which they are to be grown. The gene source for the quality character is unlikely to be adapted in this way, and it must therefore be used as one parent of a cross to produce hybrids. Wheat, oats and barley normally breed true, being self-pollinating plants, and must be artificially cross-pollinated to produce a population containing new combinations of genes. The other parent or parents must be adapted ones to bring into the population genes for yield, straw strength, disease resistance and other characters. For 5 or 6 years after making a cross, natural self-pollination results in the assortment of genes and must be followed by screening tests and selection, not only for the quality character but for all others of significance to agriculture. The amount of seed available per sample will be small since from each plant, or a group of a few plants, seed must be set aside to grow the next generation.

Some 6 or 7 years after making a cross a new variety has, in fact, been created, but two more important steps still have to be taken and may occupy a further 6-8 years. The thorough testing of a new variety in this country normally needs 6 years and about fifty replicated trials. Quality assessments must be made from many of these trials in comparison with their control varieties to establish the extent and reliability of any improvement in quality. In parallel with yield testing, seed stocks of the variety must be produced. These have to be agriculturally acceptable, i.e. exhibit the characteristics of the new variety without contamination and be free from weed seeds and disease. In addition, stocks must be produced which conform to the legal requirements by being uniform for virtually all recognizable characters, before it is permissable to advertize or sell them.

Breeding a new variety to meet a particular quality standard, whether it be for industrial or nutritional purposes, is a lengthy procedure which breeders only undertake if there is a reasonable prospect of subsequent commercial use. The first step in a breeding programme-determining the direction in which research should proceed-is, therefore, of particular importance.

\section{Nutritional factors}

It is convenient to consider the nutritional factors which might form the basis of breeding programmes under five headings: starch, oil, insoluble carbohydrate, protein and minor components. Under the last heading is included the possibility of modifying vitamin or mineral contents, or of removing toxic substances. The last are important in some crops, for example erucic acid in some Brassica seeds and alkaloids in Lupinus. With cereal grains, however, there is no toxicity problem at present and the minor nutritional factors do not seem to provide scope for breeding work. Although Greer, Ridyard \& Kent (1952) reported that Bersee and Vilmorin 27 wheats were higher in vitamin $B_{1}$ content than other wheats they tested, and Greer, Pringle \& Kent (1952) found small differences in iron content, it is doubtful whether either of these observations has dietary significance.

Little attention has yet been given to searching for variants of the cereal crops with unusual composition, but it is very probable that more of these will be discovered. In particular, the chemical composition of the artificial mutants of barley, 
which have been produced in large numbers, should be examined. Because an increase in one component may be matched by a decrease in another a complete analysis is essential.

Starch. Variations in starch type have not played much part in cereal breeding. Variations in starch content are important but are best considered from the complementary viewpoint of the amount of the other constituents. The type of starch, or more precisely the liability of starch granules to structural damage during the milling of wheat into flour, is certainly of significance to the baking industry and therefore does receive attention. This, however, is only indirectly of nutritional significance.

Differences in starch composition exist in barley. A gene producing waxy endosperm containing an excess of amylopectin has long been known, but seems to have had little application. A recent discovery of another variant may be more important and strengthens the view that diligent search may bring many other variants to light. The six-rowed variety, Glacier, after being maintained at the Scottish Plant Breeding Station for 18 years, was found to have an amylose content much higher than normal for barley (Merritt, 1967 ). This condition has now been shown to be due to a single recessive gene which does not occur in other stocks of Glacier (Walker \& Merritt, 1969). There is evidence that the gene also increases the protein content of the grain (Merritt \& Walker, r 969 ). It is too early yet to know whether the increase in the amylose fraction will be significant in animal nutrition. It may well be of use in the newer techniques of brewing which by-pass the traditional manufacture of malt. Work is in progress in Scotland to transfer the gene to adapted varieties and small amounts of the Glacier stock have been released to other breeders.

The identification by means of electrophoresis of two $x$-amylases in barley and the demonstration that there are varietal differences (Frydenberg \& Nielsen, I966) indicates that other differences in the structure of barley starch may also exist.

Oil. The oil content of wheat and barlcy is low and has received little attention from breeders. In oats, however, oil makes a significant contribution to the total energy value of the harvested crop. Furthermore, there are appreciable varietal variations in oil content: the highest levels are found mostly in old winter-hardy varieties. The decline in oil content is due to the neglect of this character by breeders who have been given little incentive to maintain it. Such a decline sometimes happens because a negative correlation exists between a quality character and some other that is judged more important. For example, thick husk and stiff straw in oats are associated. Correlations between the amounts of various components of the grain or between some of them and yield are known to exist and may affect the results of selection. The correlations may be of environmental origin but may also have a genetic basis. Jenkins ( 1969 ) has investigated some of these relationships in a group of thirty-six crosses involving some widely different oat varieties. He found that oil content (as a proportion of dry weight) was not correlated with either yield or nitrogen content. Oil yield was positively correlated with yields per unit area of both grain and protein. Thus, it should be possible to produce high-yielding varieties with high oil content, should there be a demand for such varieties. 
Insoluble carbohydrate. In oats and barley grain the insoluble carbohydrate exists largely in the fibrous material of the husk. Although useful as roughage, husk has low nutritive value and might be better left in the field during harvest, as happens with wheat. Technically this is quite possible as varieties of both oats and barley with naked grain are known. Conversely wheat with covered grain is also known but is regarded as primitive and agriculturally undesirable. Small breeding programmes with both oats and barley are under way at the Plant Breeding Institute to investigate the feasibility of producing adapted varieties with naked grain. The problems with oats have recently been reviewed (Jenkins, 1968). Barley would be easier to handle as there are no complications resulting from the multiflorous character which is always associated with naked grain in oats. The grain of such varieties would have very high energy densities and would provide the compounder of animal feedingstuffs with a useful raw material.

Even if varieties were bred to be equivalent to the best now available, their lack of husk would mean they would be much lower yielding. Without a premium, such varieties would have little hope of survival in commercial use. It is important when discussing the evaluation of varieties in terms of quality, to distinguish between the quantity in a unit weight of crop product and the quantity produced from a unit area of land. High energy content per ton may be an important concept for the compounder, but the farmer is more concerned with production per acre. The two are not necessarily compatible.

Protein content. Strong negative correlation normally exist between grain protein content (expressed as a proportion of dry matter) and grain yield (Bell \& Lupton, 1962; Kirby, I968; Jenkins, I969; Whitehouse, 1969). This can be observed when plots of several varieties at one site or of one variety at several sites are considered. The results from trials commonly show that the highest-yielding varieties are those with the lowest protein percentages. The correlations, however, are such that high yields of grain are usually associated with high yields of protein. Thus the varieties which it is economic for farmers to grow are not necessarily those which produce grain best suited to the compounder's requirements.

Before any progress can be made in breeding for improved protein content it is necessary to demonstrate that varieties exist which lie off the yield-protein regression line. Varieties of barley with high protein content (up to $20 \%$ of the dry weight) are common; most varieties grown under unfavourable conditions will fail to fill their grain with carbohydrate and consequently will have a high protein percentage. Many of the artificially produced mutants having high protein contents are in reality low producers of carbohydrate. Wheat varieties giving high protein yields have been used by Johnson, Whited, Mattern \& Schmidt (1969) in breeding programmes in the USA. They have produced varieties combining high yield and high protein levels. It is not known whether similar results can be obtained in Great Britain where yield levels of 5 or 6 tons per ha are expected.

In an experiment involving the application of water and nitrogen fertilizer to five spring barley varieties, Kirby (I968) has shown that a Mediterranean variety, Algerie 48 , although lower yielding than the adapted varieties, Proctor and Deba 
Abed, produced significantly more protein per unit area of land. Although Algerie 48 is far removed from the type of variety acceptable in this country, there is scope for simultaneous improvement in protein yield and protein content, particularly in varieties capable of standing high dressings of applied fertilizer.

Amino acid analysis. In relation to the requirements of non-ruminant animals, barley proteins have a low biological value, the primary cause being a shortage of lysine, although methionine and cystine may also be limiting. Attempts to improve this situation by producing a high-lysine barley illustrate the early stages of a breeding programme. The economic value of such a variety was investigated by Carpenter $\&$ Taylor ( 1968 ), but the position is by no means clear because new sources of lysine, especially those of fungal origin, are still being examined. A really cheap source of lysine in a form readily available to non-ruminant animals could invalidate a breeding programme.

Tests for lysine used initially were slow but established a relationship between the protein and lysine contents of barley grain. Differences in protein level caused by environmental conditions are not proportional to the differences in lysine content.

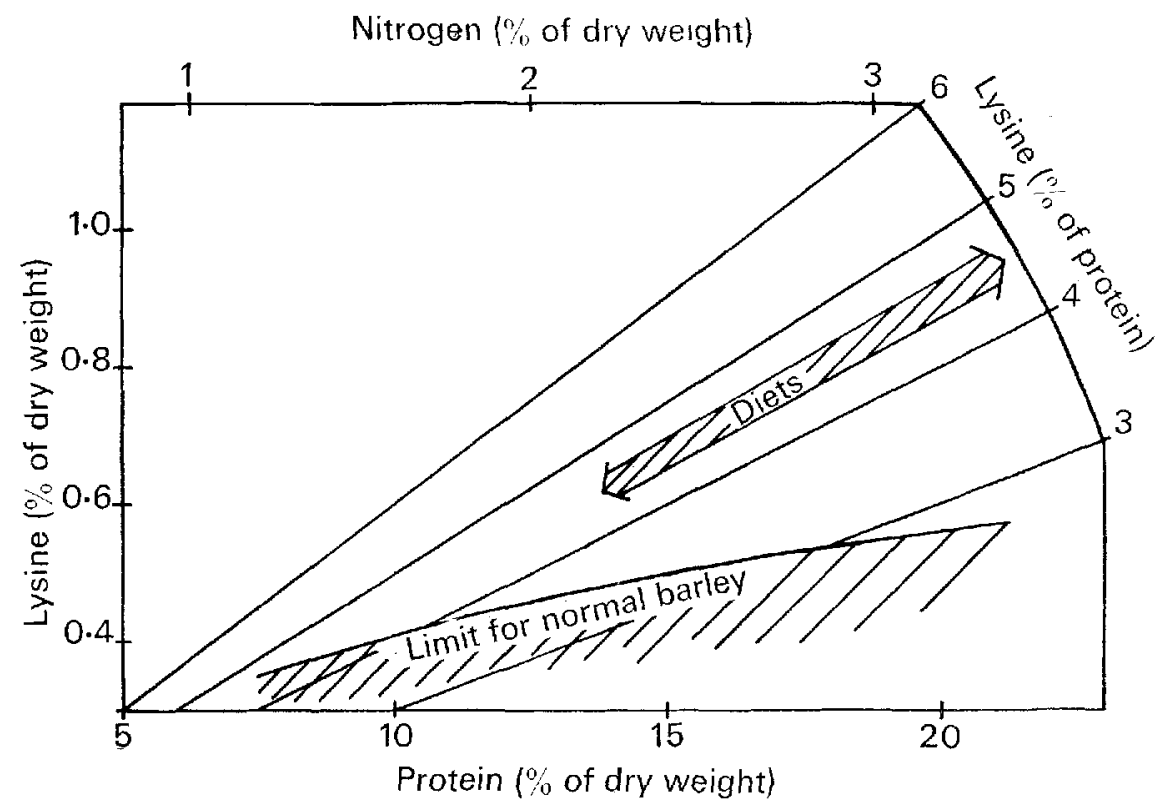

Fig. I. Composition of barley grain and of diets for non-ruminants in terms of lysine and protein contents.

As protein levels increase the percentage of lysine in the protein falls although the total amount of lysine in the grain is still a little higher than in a low-protein sample of the same variety. The gap between the dietary requirements of the nonruminant and the composition of barley is indicated approximately in Fig. I. The right-hand part of the barley curve represents material grown under experimental conditions and not available commercially. 
As there appeared to be a good case for devising a breeding programme, a more rapid test was sought and screening of varieties was begun at the Plant Breeding Institute. Meanwhile Hagberg, Munck \& Karlsson (1969), who undertook a much larger survey, reported that an Abyssinian variety, CI 3947, in the United States Department of Agriculture collection combines high lysine and high protein contents. Seed has been distributed to breeders who now have to confirm that the relationship applies under their conditions and that after hybridization plants can be selected which still have the improved protein type. Its nutritional value has yet to be determined by comparative feeding trials. The differences in amino acid composition between barley grains with high protein and grains with low protein levels are likely to be due to the different proportions of structural and storage proteins. Hordein, the main storage protein of barley, is low in lysine while the structural proteins contain high levels of lysine (Folkes \& Yemm, I956). That hordein steadily increases in amount during development of the grain was shown by Bishop (1930). At the Plant Breeding Institute a preliminary examination of the grain of a barley crop (E. T. Whitmore, unpublished) showed that lysine content as a percentage of protein content fell from above 6 to under 4 as the grain ripened. In order to examine this and other aspects of the feeding value of barley in more detail, four varieties were grown in a glasshouse and supplied with culture solution. The supply of nitrogen was terminated at four stages of growth so that grain samples of various nitrogen contents were obtained. Four harvests were taken after anthesis, the last being when most of the grain was ripe. The varieties were Algerie 48 , Deba Abed, Proctor and Sito Hadaka, a Japanese variety.

Table I. Values of six grain characters from plants grown in a glasshouse using four nitrogen regimes, four varieties and four harvest dates

(Varieties: I, Algerie 48; 2, Deba Abed; 3, Proctor; 4, Sito Hadaka. Yields in g/plot of eighteen plants)

\begin{tabular}{|c|c|c|c|c|c|c|}
\hline & $\begin{array}{l}\text { Grain } \\
\text { yield/plot }\end{array}$ & $\begin{array}{l}\mathrm{N} \% \text { of } \\
\text { dry wt }\end{array}$ & $\begin{array}{l}\text { Protein } \\
\text { yield/plot }\end{array}$ & $\begin{array}{l}\text { Lysine } \% \\
\text { of dry wt }\end{array}$ & $\begin{array}{l}\text { Iysine } \\
\text { yield/plot }\end{array}$ & $\begin{array}{l}\text { Lysine } \% \\
\text { of protein }\end{array}$ \\
\hline \multicolumn{7}{|c|}{ (a) Nitrogen } \\
\hline I & $29^{\circ} 9$ & 1.47 & $2 \cdot 71$ & 0.264 & 0.077 & $2 \cdot 91$ \\
\hline 2 & $59 \cdot 5$ & $1 \cdot 79$ & 6.59 & 0.320 & 0.184 & $2 \cdot 86$ \\
\hline 3 & $62: 4$ & 2.07 & $7 \cdot 85$ & 0.344 & 0.210 & $2 \cdot 69$ \\
\hline ( $1 \%$ LSD) & $\begin{array}{c}40 \cdot 0 \\
(111 \cdot 5)\end{array}$ & $\begin{array}{c}3.10 \\
(0.16)\end{array}$ & $\begin{array}{c}7 \cdot 61 \\
(1 \cdot 79)\end{array}$ & $\begin{array}{c}0.462 \\
(0.020)\end{array}$ & $\begin{array}{c}0.180 \\
(0.038)\end{array}$ & $\begin{array}{c}2 \cdot 40 \\
(0.22)\end{array}$ \\
\hline \multicolumn{7}{|l|}{ (b) Variety } \\
\hline 1 & $57 \cdot 0$ & $2 \cdot 31$ & $7 \cdot 98$ & 0.348 & 0.196 & $2 \cdot 43$ \\
\hline 2 & 53.0 & $x \cdot 99$ & $6 \cdot 46$ & 0.345 & 0.176 & $2 \cdot 86$ \\
\hline 3 & $45 \cdot 2$ & $I \cdot 90$ & $5 \cdot 19$ & 0.336 & 0.146 & $2 \cdot 91$ \\
\hline$(1 \%$ LSD) & $\begin{array}{l}36 \cdot 6 \\
(9 \cdot 3)\end{array}$ & $\begin{array}{c}2 \cdot 25 \\
(0 \cdot 14)\end{array}$ & $\begin{array}{c}5 \cdot 13 \\
(x \cdot 2 I)\end{array}$ & $\begin{array}{r}0.3^{6 t} \\
\text { (N.S.) }\end{array}$ & $\begin{array}{c}0.133 \\
(0.030)\end{array}$ & $\begin{array}{c}2 \cdot 65 \\
(0 \cdot 24)\end{array}$ \\
\hline \multicolumn{7}{|l|}{ (c) Harvest } \\
\hline I & $33 \cdot 6$ & $2 \cdot 43$ & $5^{*}$ I I & 0.396 & 0.133 & $2 \cdot 67$ \\
\hline 2 & $48 \cdot 0$ & $2 \cdot 0 \mathrm{I}$ & 6.01 & 0.339 & 0.163 & $2 \cdot 77$ \\
\hline 3 & $5 I \cdot 4$ & $\mathbf{I} \cdot 98$ & $6 \cdot 17$ & 0.334 & $0 \cdot 169$ & $2 \cdot 77$ \\
\hline (1 $\%$ LSD) & $\begin{array}{l}58 \cdot 7 \\
(6 \cdot 0)\end{array}$ & $\begin{array}{l}2.03 \\
(0.09)\end{array}$ & $\begin{array}{c}7 \cdot 47 \\
(0.79)\end{array}$ & $\begin{array}{c}0.322 \\
(0.025)\end{array}$ & $\begin{array}{c}0.187 \\
(0.022)\end{array}$ & $\begin{array}{c}2.65 \\
\text { (N.S.) }\end{array}$ \\
\hline
\end{tabular}

LSD, least significant difference. 
A summary of the results for the three treatments, nitrogen, variety and harvest date are given in Table $\mathrm{I}$, together with the $\mathrm{I} \%$ least significant differences. Six characters are considered here but a more detailed analysis will be published later. From Table $\mathrm{ia}$ it can be seen that a wide range of protein levels was obtained and that lysine as a percentage of protein fell as protein levels rose. Yields of grain, protein and lysine are given in $\mathrm{g} / \mathrm{plot}$ of eighteen plants.

Table $\mathrm{Ib}$ confirms the observation by Kirby ( $\mathrm{I} 968$ ) that Algerie 48 is capable of giving very high yields of protein by virtue of its high nitrogen content. Under the conditions of this experiment it also gave high yields of grain, but would not do so in field plots. There was no significant difference, due to variety, in lysine as a percentage of dry weight, but there were varietal differences in lysine as a percentage of protein. These largely reflect the differences in protein contents, the adapted varieties Deba Abed and Proctor having the lowest nitrogen percentages and the protein richest in lysine.

Table Ic shows the increase in dry weight of grain protein and lysine during grain filling. The initial fall in nitrogen percentage is in contrast to the findings from field plots. There were no significant differences in lysine as a percentage of protein due to harvest date, nor any significant interactions with the other treatments. The indication from this is that the biological value of the protcin remains constant at least during the later stages of grain filling. By the time of the first observation nearly two-thirds of the protein was already present in the grain, and the levels of lysine in the protein were abnormally low, so further observations are required.

\section{Grain structure and post-harvest treatment}

As an alternative to chemical screening tests, simple changes in grain morphology could be used as a means of selection. Variations in the number of aleurone cells of the endosperm exist in barley (Sawicki, 1950). Selection for high or low number would be fairly easy and could be a useful method provided an association between cell number and a nutritional factor could be established. Embryos are a rich source of protein. Two samples of barley embryos tested at the Plant Breeding Institute had similar compositions. Their protein contained about $7 \%$ of lysine and provided about $38 \%$ of the dry weight of the embryo. Selection for larger embryos could also produce a useful response.

There are other possible ways of improving the feeding value of the grain. Bearing in mind the relationship between yield and protein content it may be economic to grow the highest-yielding varieties and fractionate the ground grain by air-classification into protein-rich and protein-poor parts. The former, containing embryos and aleurone, could be used directly for animal feeding while the latter would provide a substrate for fungal enrichment. A further possibility is to utilize the observations of Jones \& Pierce (1967) that during the germination of barley the amount of lysine in the grain increased over a 6 -day period by about $40 \%$. Its distribution in the grain altered, but an increase of this magnitude is probably more than could be achieved by breeding. A varietal survey is being undertaken 
to find if this value is consistent. Preliminary observations on four varieties do not confirm it: only one increased in lysine content and then only by a small amount. However, further investigation is necessary.

\section{Conclusion}

The composition of cereal grains has had relatively little attention so far from plant breeders. 'There appears to be scope for improvement in the quantity and quality of the proteins and in the quantities of some other components, notably oil and fibre. Changes in starch composition are also evidently possible. The indications are that searches for plant material with special qualities are likely to be worth while. Two problems face the breeders. First, they must decide whether it is worth embarking on long-term research programmes to improve particular aspects of quality. Second, they must ensure that varieties which have valuable quality characters reap an adequate economic return for those who grow them. Co-operation between breeders and nutritionists should assist in the solution of both these problems.

\section{REFERENCES}

Bell, G. D. H. \& Lupton, F. G. H. (1962). In Barley and Malt. [A. H. Cook, editor.] New York and I,ondon: Academic Press Inc.

Bishop, L. R. (1930). F. Inst. Brew. 36, 336.

Carpenter, K. J. \& Taylor, J. H. (1968). Proc. Nutr. Soc, 27, 1.A

Folkes, B. F. \& Yemm, E. W. (1956). Biochem. Y. 62, 4.

Frydenberg, O. \& Neilsen, G. (1966). Hereditas 54, 123.

Greer, E. N., Ridyard, H. N. \& Kent, N. L. (1952). F. Sci. Fd Agric. 3, 12.

Greer, E. N., Pringle, W. J. S. \& Kent, N. L. (1952). भ. Sci. Fd Agric. 3, 16.

Hagberg, A., Munck, L. \& Karlsson, K-E. (1969). U.S.D.A. Press Release i 72-69, Wash.

Jenkins, G. (1968). N.A.A.S. q. Rev. 79, 120.

Jenkins, G. (1969). \%. agric. Sci., Camb. 72, 3 I r.

Johnson, V. A., Whited, D. A., Mattern, P. J. \& Schmidt, J. W. (1969). Proc. 3rd int. Wheat symp. (In the Press.)

Jones, M. \& Pierce, J. S. (1967). F. Inst. Brew. 73, 577.

Kirby, E. J. M. (т968). \%. agric. Sci., Camb. 71, 47.

Merritt, N. R. (1967). F. Inst. Brew. 73, 583 .

Merritt, N. R. \& Walker, J. T. (1969). F. Inst. Brew. 75, I56.

Sawicki, J. (r95o). Bull. Acad. pol. Sci. Lettres. Sér. B, r, ror.

Walker, J. T. \& Merritt, N. R. (1969). Nature, Lond. 221, 482.

Whitehouse, R. N. H. (1969). Rep. Pl. Breed. Inst. 1969, p. 6.

\section{Practical problems concerning the marketing of cereals with improved protein value}

By Roger Mossberg, Plant Breeding Institute, Weibullsholm, Landskrona, Sweden

The marketing of new cereal varieties with improved protein value only might today meet with scveral practical problems. I intend to discuss some of these problems here, mainly those arising in the industrialized countries in connexion especially with a possible utilization of their cereal production for reducing the shortage of food in the developing world. 